\title{
Når kreftene renner vekk
}

\author{
Vi som sliter med kronisk utmattelse, opplever at mange leger og Nav ikke kan nok om dette. Uten kunnskap \\ om hvordan det oppleves kan man heller ikke forstå. Veien frem er derfor blitt veldig tung og unødvendig slit- \\ som. Mange av oss som har vært igjennom kreftbehandling, fikk aldri høre om kronisk utmattelse underveis \\ i behandlingsforløpet.
}

Vi har et inderlig ønske om at Tidsskriftet kan rette mer oppmerksomhet mot kronisk utmattelse (fatigue). Kanskje kan det bli lettere for dem som kommer etter oss hvis de får mer informasjon underveis. Hvis legene og Nav forstår, kan vi trolig takle plagene bedre. Har vi legene med oss, kan det bli enklere å forklare hvordan vi har det for familie og venner. Vi kan få bedre livskvalitet og positive effekter på flere områder.

Kronisk utmattelse er vanskelig å forklare med få ord. Jeg har likevel gjort et forsøk.

\section{Hverdagsliv}

Du makter ikke gjøre nødvendige ting i hjemmet

Du makter ikke å ta deg av familie, barn, barnebarn og venner slik du ønsker

Du føler ikke at alle dager er like tunge, noen dager kan faktisk være bra

Du vet aldri når og hvor du plutselig står uten krefter

Du må hver dag, hele tiden, sortere ut hva du skal gjøre og ikke gjøre, du må prioritere hardt

Du står klar til å utføre en oppgave, men du må bare gi opp, kreftene «renner» plutselig vekk - der og da, uten forvarsel,

du står og skjelver, klarer ikke mer, en usigelig tunghet kommer over deg

Du bruker tid hver dag til å planlegge; hva kan du klare, hva må du la være

Du gjør litt, hviler, gjør litt, hviler igjen...

Du kan glemme å gjøre noe enkelte dager

Du kan føle at å holde en elektrisk tannbørste blir for tungt

\section{Det sosiale liv}

Du kan mangle initiativ og overskudd

Du orker sjelden å invitere venner, det krever for mye

$\mathrm{Du}$ forsaker hyggelige aktiviteter fordi du blir sliten av mange mennesker rundt deg, av mye lyd
Du kan falle utenfor i diskusjoner fordi du glemmer hva du skal si

Du er redd du skal såre noen

Du kan faktisk si ting du ikke mener

Høytider er en stor belastning for de krever ekstra av oss

\section{Trening og friluftsliv}

Du kan ikke trene på vanlig måte

Du må ikke trene for hardt, virkningen blir motsatt

Du kan ikke gå de samme turene som andre i skog og fjell fordi du vet ikke hvor langt du klarer å gå, om du klarer å komme deg hjem på egne ben

Du vet aldri når du plutselig står der og ikke makter å ta et skritt videre

\section{Følelsesliv}

Du kan ha et flatere følelsesliv

Du kan bruke lengre tid på å ta innover deg både gleder og sorger

Du kan tvile på egen dømmekraft

Du føler deg dum, selvtilliten blir dårlig

Du faller utenfor

Du kommer inn i en vond spiral

Du tenker og handler irrasjonelt når du er utmattet

Du kan få merkelige oppfatninger av ting når du har en dårlig dag

Du føler at du blir betraktet som lat

Du er ikke syk i «viljen», men kropp og hode nekter å være med

Du vil, men får det ikke til

\section{Arbeidsliv}

Du må kunne ta pauser, kanskje bytte dag

Du tåler ikke stress og mas

Du tåler ikke for stort ansvar og press

Du tåler ikke plutselige omstillinger

Du må ha forutsigbarhet

Du tåler ikke å få vanskelige vurderinger foran deg

Du glemmer

Du har problemer med å konsentrere deg
Du klarer ikke å si de rette tingene til rett tid fordi du glemmer dine egne momenter

Du blir misforstått

Enkelte kan klare en liten stilling med lett arbeid, men arbeidslivet har ikke slike stillinger,

du er ikke ønsket når du har mange begrensninger

Du klarer derfor ikke komme ut i arbeidslivet igjen etter det du har vært igjennom

\section{Livskvalitet}

Du savner til fulle å kunne være en del av en normal hverdag

Du savner gleden av å klare det andre klarer, det du klarte før

Du ønsker å slippe planlegging og hensyntagen til kroppen hver dag

Du føler sorg og savn over tapt identitet

Over at du ikke får delta i samfunnet på lik måte med andre

Over å falle utenom det sosiale liv

Over ikke å få delta i arbeidslivet, føle at du gjør noe nyttig og ha kollegialt samvær

Over helsevesen, leger og Nav som ikke forstår og mistror

Over menneskene rundt deg som ikke forstår

Du mister mye av deg selv og har ikke kontroll og styring på livet ditt

Det du sliter med, synes ikke på deg

Hva slags livskvalitet er dette?

\section{Tone Kind Brekke}

tonekindbrekke@hotmail.com

Tone Kind Brekke (f. 1958) har merkantil bakgrunn.

Ingen oppgitte interessekonflikter.

Mottatt 6.2. 2014 og godkjent 17.2. 2014. Redaktør: Erlend Hem. 